\title{
Does des-acyl ghrelin improve glycemic control by decreasing acylated ghrelin levels?
}

\author{
Bruce D Gaylinn 1, Leon S Farhy ${ }^{1,2}$, Ralf Nass', Jenny Tong ${ }^{3}$ and Michael 0 Thorner ${ }^{1}$ \\ ${ }^{1}$ Division of Endocrinology and Metabolism, Department of Medicine and ${ }^{2}$ Center for Diabetes Technology, \\ University of Virginia, PO Box 801411, Charlottesville, Virginia 22908, USA and ${ }^{3}$ Division of Endocrinology, \\ Department of Medicine, Duke University, Durham, North Carolina 27710, USA
}

Correspondence should be addressed to B D Gaylinn Email bg2g@virginia.edu

\section{Dear Editor,}

In a recent paper on infusion of des-acyl ghrelin (DAG) in type 2 diabetic subjects, Özcan et al. (1) reported improvement in glycemia accompanied by a decrease in circulating acyl ghrelin (AG) levels. While the results clearly demonstrate the anti-diabetogenic potential of DAG, they also bring to mind Dr Tong's DAG infusion studies (2) in which we did not observe a decline in AG. We note that in (1), a C-terminal capture sandwich assay was used for ghrelin assay and, in (2), we used an N-terminal AG-specific capture antibody. It is therefore possible that the differences between the two studies are due to the specificity of the assay methodology. In particular, when high concentrations of DAG are present, they may compete for capture at the C-terminal assay antibody and interfere with the detection of AG, which is not the case if an N-terminal capture assay is used.

In (1) and (2), DAG was infused at pharmacological doses such that circulating levels exceeded those of AG by 500- to 1000-fold. In (1), the units for DAG concentrations during the infusion appear to be erroneous: they were listed as $\mathrm{pg} / \mathrm{ml}$ but were probably meant to be $\mathrm{ng} / \mathrm{ml}$. Therefore, depending on the assay parameters, and more specifically on the binding capacity of the capture antibody, competition at the C-terminal antibody is possible. In (2), no suppression of AG was observed during infusion of DAG producing similar levels and time course to those reported in (1) (see Fig. 1). One notable difference is that overweight type 2 diabetic patients were studied in (1), while non-obese healthy subjects were studied in (2).

This problem of assay capture competition has been previously reported in the supplement of our paper
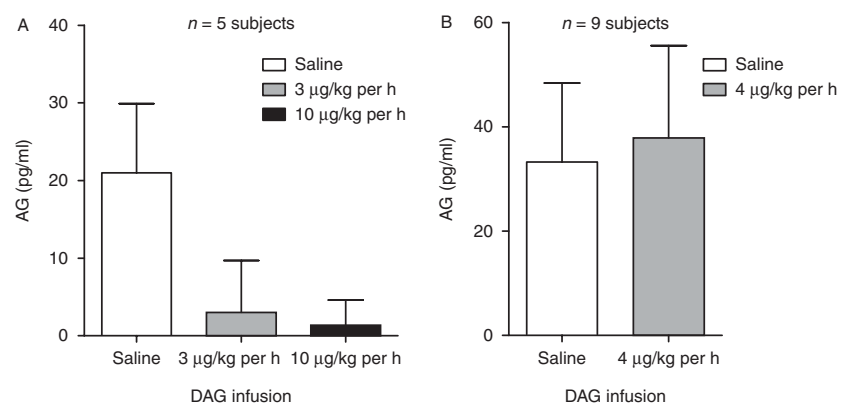

Figure 1

Plasma AG levels during DAG infusion. Data from ref.

(1) (A) and ref. (2) (B). Panel A represents an overnight infusion while panel $B$ is only $210 \mathrm{~min}$, but ref. (1) also reports similar AG suppression at $240 \mathrm{~min}$.

characterizing our own ghrelin assay (3) and is the reason why we have always used a specific N-terminal AG capture antibody. Similarly, in the AG infusion studies in (2), we found that, when assaying DAG with a C-terminal capture antibody, the high levels of AG did inhibit the detection of DAG. We have therefore switched to N-terminal-specific capture for the DAG assay as well (2).

In conclusion, competition by pharmacological levels of DAG for the C-terminal capture antibody in the AG assay used in (1) may produce an artifact of AG suppression by DAG not observed in studies using specific N-terminal AG capture antibody. Therefore, while the results on improvement in glycemia remain extremely interesting and important, they are not necessarily due to suppression of AG by DAG.
(C) 2015 European Society of Endocrinology Printed in Great Britain
Published by Bioscientifica Ltd 


\section{References}

1 Özcan B, Neggers SJ, Miller AR, Yang HC, Lucaites V, Abribat T, Allas S, Huisman M, Visser JA, Themmen AP et al. Does des-acyl ghrelin improve glycemic control in obese diabetic subjects by decreasing acylated ghrelin levels? European Journal of Endocrinology 2014170 799-807. (doi:10.1530/EJE-13-0347)

2 Tong J, Dave N, Mugundu GM, Davis HW, Gaylinn BD, Thorner MO, Tschop MH, D'Alessio D \& Desai PB. The pharmacokinetics of

acyl, des-acyl, and total ghrelin in healthy human subjects. European Journal of Endocrinology 2013168 821-828. (doi:10.1530/ EJE-13-0072)

3 Liu J, Prudom CE, Nass R, Pezzoli SS, Oliveri MC, Johnson ML, Veldhuis P, Gordon DA, Howard AD, Witcher DR et al. Novel ghrelin assays provide evidence for independent regulation of ghrelin acylation and secretion in healthy young men. Journal of Clinical Endocrinology and Metabolism 200893 1980-1987. (doi:10.1210/jc. 2007-2235) 